\title{
PENCEGAHAN KORUPSI PADA LEMBAGA PEMASYARAKATAN MELALUI PELEMBAGAAN KHUSUS PERS PENJARA
}

\author{
Oleh: \\ WENCISLAUS S. NANSI \\ Dosen Fakultas Hukum Universitas Atma Jaya Makassar \\ e-mail: wencislaus82@gmail.com
}

\begin{abstract}
ABSTRAK: Tulisan dengan judul Pencegahan Korupsi Pada Lembaga Pemasyarakatan Melalui Pelembagaan Khusus Pers Penjara merupakan sumbangan pemikiran terhadap pembenahan lembaga pemasyarakatan dalam upaya pencegahan tindak pidana korupsi pada lembaga pemsayarakatan. Tulisan ini membedah dua hal yakni peran pers terhadap upaya pemberantasan korupsi dan urgensitas pelembagaan pers penjara sebagai upaya pencegahan tindak pidana korupsi pada lembaga pemasyarakatan. Kesimpulan dari tulisan ini adalah pentingnya pelembagaan khsusus pers penjara dengan diatur dalam regulasi khusus atau revisi terhadap peraturan perundang-undangan yang telah ada, baik undang-undang pers atau undang-undang lembaga pemasyarakatan. Tulisan ini merupakan kajian normatif dengan pendekatan data sekunder.
\end{abstract}

\section{KATA KUNCI: Korupsi, Pers, Lembaga Pemasyarakatan}

ABSTRACT: This Writing with title Prevention of Corruption in Penitentiaries Through the Special Institution of the Prison Press is a contribution of thought to the reform of correctional institutions in efforts to prevent corruption in penitentiary. This paper examines two things, namely the role of the press in efforts to eradicate corruption and the urgency of the institutionalization of the prison press as an effort to prevent criminal acts of corruption in correctional institutions. The conclusion of this paper is the importance of the institutionalization of the prison press in particular by being regulated in specific regulations or revisions to existing legislation, both press laws or penal law. This paper is a normative study with a secondary data approach.

KEYWORDS: Corruption, Press, Prison

\section{PENDAHULUAN}

Kejahatan korupsi yang terjadi di Indonesia semakin hari semakin mengkhawatirkan karena telah memberikan dampak buruk bagi kehidupan berbangsa dan bernegara. Realita telah banyak membuktikan bahwa korupsi tidak hanya menghancurkan perekonomian tetapi juga telah merusak sistem demokrasi, sistem politik, dan juga mengancam ketahanan nasional. Korupsi yang begitu masif tersebut semakin mengewatirkan karena terjadi bukan hanya pada level pemerintahan baik pusat maupun daerah, serta lembaga legislative tetapi juga telah mearasuki lembaga penegak hukum yang terintegrasi dalam system peradilan pidana seperti Kepolisian, Kejaksaan, Pengadilan dan Lembaga Pemasyarakatan. 
Dari sekian banyak faktor penyebab korupsi, Bibit Samad Riyanto ${ }^{1}$ mengatakan lima hal yang dianggap berpotensi menjadi penyebab tindakan korupsi. Pertama adalah sistem politik, yang ditandai dengan munculnya aturan perundang-undangan, seperti Perda, dan peraturan lain ; kedua, adalah intensitas moral seseorang atau kelompok; ketiga adalah remunerasi atau pendapatan (penghasilan) yang minim; keempat adalah pengawasan baik bersifat internaleksternal; dan kelima adalah budaya taat aturan. Sementara itu Rahman Saleh ${ }^{2}$ merinci ada empat faktor dominan penyebab merajalelanya korupsi di Indonesia, yakni faktor penegakan hukum, mental aparatur, kesadaran masyarakat yang masih rendah, dan rendahnya 'political will'

Berdasarkan hal tersebut, berbagai upaya telah dilakukan baik melalui upaya pencegahan maupun upaya-upaya represif. Namun berbagai upaya tersebut telah dilakukan namun praktek korupsi terus saja terjadi. Menurut Indriyanto Senoadji bahwa untuk meminimalisasi tindak pidana korupsi yang telah menjadi permasalahan sistematik dan terstruktur yang sangat utuh terakar kuat serta permanen sifatnya, diperlukan usaha yang maksimal bagi penegakan hukum,yaitu melalui pendekatan system itu sendiri(systematic approach) ${ }^{3}$. Pendekatan sistematik yang ditawarkan oleh Indriyanto Seno Adji tersebut,memiliki tiga lapis makna,yaitu sebagai berikut: ${ }^{4}$ 1) Maksimalisasi peran sistem peradilan Pidana secara luas;

\footnotetext{
${ }^{1}$ Bibit Samad Rianto (2009), Undang-undang Pengadilan Tipikor dan Eksistensi Komisi Pemberantasan Korupsi, dalam Amir Syarifudin, dkk ( Penyunting) Bunga Rampai Potret Penegakan Hukum di Indonesia, Jakarta: Komisi Yudisial, Republik Indonesia

${ }^{2}$ Saleh, Abdul Rahman. “Korupsi Tergolong Extraordinary"

http://www.arsip.pontianakpost.com/berita/index.asp? Berita $=$ Pinyuh\&id $=129619$
}

2)Koordinasi dan Kepaduan antara aparat-aparat penegak Hukum (polisi,Jaksa dan Pengadilan,bahkan termasuk advokat);dan 3)Pembenahan hukum yang meliputi struktur hukum atau legal structure,substansi hukum atau legal substance dan budaya hukum atau legal culture.

Salah satu bagian penting dalam upaya penegakan hukum di Indonesia,termasuk pemberantasan tindak pidana korupsi adalah pembenahan terhadap Lembaga pemasyarakatan. Berdasarkan UU. No. 12 Tahun 1992 tentang Lembaga Pemasyarakatan dalam Pasal 1 butir 3, Lembaga Pemasyarakatan adalah tempat untuk melaksanakan pembinaan Narapidana dan Anak Didik Pemasyarakatan ${ }^{5}$,yang dilaksanakan secara terpadu antara pembina, yang dibina, dan masyarakat untuk meningkatkan kualitas Warga Binaan Pemasyarakatan agar menyadari kesalahan, memperbaiki diri, dan tidak mengulangi tindak pidana. ${ }^{6}$

Berbicara tentang Lembaga Pemasyarakatan yang disebut "penjara",secara historis sudah ada sejak zaman Belanda dapat dirujuk pada Reglement Penjara Tahun 1917. Dalam Pasal 28 ayat (1) Reglement tersebut dinyatakan bahwa, "penjara" adalah tempat pembalasan yang setimpal atau sama atas suatu perbuatan atau tindak pidana yang telah dilakukan oleh si pelaku tindak pidana dan juga sebagai tempat pembinaan terhadap narapidana atau pelaku tindak pidana. ${ }^{7}$

\footnotetext{
${ }^{3}$ Indriyanto Seno Adji, Korupsi Kebijakan Aparatur Negara dan Hukum Pidana,Jakarta,Diadit Media,2006,hal.374

${ }^{4}$ Ibid

${ }^{5}$ Pasal 1 angka 3 UU.RI No.12 Tahun 1995 Tentang Pemasyarakatan

${ }^{6}$ Bandingkan dengan Pasal 1 butir 2 UU.No.12 tahun 1995 tentang pemasyarakatan

${ }^{7}$ Bachtiar Agus Salim, Tujuan Pidana Penjara Sejak Reglemen 1917 Hingga Lahirnya Sistem
} 
Secara ideal bahwa lembaga penjara (Lembaga Pemasyarakatan) adalah tempat membina pelaku kejahatan agar mereka jera untuk melakukan kejahatan lagi. Namun berdasarkan hasil penelitian penulis sebelumnya bahwa tujuan pemidanaan tersebut banyak gagal (tidak tercapai) karena disebabkan banyak praktek-praktek penyimpangan yang terjadi di dalam lembaga pemasyarakatan seperti jual beli sarana dan prasarna penjara, bebas keluar masuk penjara $^{8}$ bahkan bebas mengendalikan kejahatan dari dalam penjara.

Semua hal tersebut terjadi bukan semata-mata karena keberanian dari narapidana itu sendiri, tetapi ada praktek korupsi yang dilakukan oleh oknumoknum aparat lembaga pemasyarakatan. Selain masalah integritas dan prilaku menyimpang dari oknum petugas lembaga pemasyarakatan, juga banyak ditengarai oleh karena tidak adanya model kontrol yang diatur secara khusus atau terlembaga yang terlepas dari intervensi lembaga pemasyarakatan itu sendiri yang bertujuan untuk memberikan informasi secara transparan dan kritis terhadap berbagai aktivitas dan kebijakan pemasyarakatan. Yang terjadi dalam praktek selama ini adalah lembaga pemasyarakatan menjadi tempat tertutup atau terisolasi dari pengawasan masyarakat. Sehingga hal tersebut berdampak buruk terhadap praktek penjara yang menyimpang termasuk korupsi dan suap dan menyuap di dalamnya.

Berangkat dari fakta tersebut, negara seharusnya memiliki strategi yang lebih luar biasa lagi untuk mencegah dan menanggulangi tindak kejahatan korupsi

Pemasyarakatan di Indonesia Dewasa ini (Medan, Pustaka Bangsa, Pemikiran Hukum Guru Besar Dari Masa ke Masa, editor Tan Kamello, 2003). hal. 129.

${ }^{8}$ Seperti contoh kasus Operasi Tangkap Tangan Kepada Ketua Lapas Sukamiskin terakhir adalah kasus penjara sukamiskin Wahid Husein karena yang terjadi dalam lembaga pemasyarakatan. Negara tidak hanya cukup mempercayakan pada aparat penegak hukum, tetapi juga harus menciptakan satu system keterbukaan informasi, sehingga publik mampu melakukan pengawasan atau kontrol terhadap berbagai aktivitas dan kebijakan pemasyarakatan. Salah satu lembaga yang dipercayakan untuk menjadi pengawas adalah lembaga pers. Oleh karena itu tulisan ini dibuat sebagai sebuah gagasan untuk menciptakan sebuah model pengawasan khusus terhadap Lembaga Pemasyarakatan melalui pelembaga pers penjara.Oleh karena itu hal yang akan diurai dalam tulisan ini adalah a) Bagaimana peran pers dalam pnegakan hukum di Indonesia khsusunya dalam upaya pemberantasan korupsi dan b) Bagaimana urgensitas dan model pelembagaan pers penjara dalam upaya pencegahan praktek korupsi pada lembaga pemasyarakatan. Untuk menganlisis hal tersebut, penelitian ini menggunakan pendekatan normative yakni menganalisis data sekunder berupa peraturan perundang-undangan dan dokumen-dokumen hukum serta hasil hasil penelitian yang berkaitan dengan korupsi, lembaga pemasyarakatan dan pers.

\section{URGENSITAS PERS DALAM PEMBERANTASAN KORUPSI DI INDONESIA}

Indonesia adalah negara hukum sebagaimana diatur dalam UndangUndang Dasar tahun 1945 Pasal 1 ayat (3). Konsep negara hukum (Rechstaat atau Rule of Law) adalah konsep yang

dugaan jual beli fasilitas penjara dan suap izin keluar masuk lapas( Sumber:

https://nasional.kompas.com/read/2018/07/24/140817 01/pimpinan-dpr-minta-napi-koruptor-takdiistimewakan-di-lapas. 
menempatkan hukum sebagai supremasi tertinggi dalam pelaksanaan kehidupan berbangsa-bernegara. Salah satu ciri dari negara hukum adalah adanya kebebasan informasi melalui penguatan lembagalembaga pers. Dalam UUD 1945 Pasal 28F menegaskan bahwa : Setiap orang berhak untuk berkomunikasi dan memperoleh informasi untuk mengembangkan pribadi dan lingkungan sosialnya, serta berhak untuk mencari,memperoleh,memiliki,menyimp an,mengolah,dan menyampaikan informasi dengan menggunakan segala jenis saluran yang tersedia.

Amanah konstitusi tersebut selanjutnya dipertegas dalam produk hukum khusus tentang pers yakni UU No. 40 Tahun 1999 dimana mengatur tentang peran dalam menjamin penegakan hukum. ${ }^{9}$ Serta salah satu wujud kedaulatan rakyat menciptakan kehidupan bermasyarakat, berbangsa dan bernegara yang demokratis. ${ }^{10}$ Serta fungsi informasi dan fungsi kontrol.

Dalam kaitan dengan aktivitas jurnalistik atau pers, setidaknya ada tiga aspek hubungan pers dengan penegakan hukum. ${ }^{11}$ Pertama; pers sebagai obyek penegakan hukum atau yang terkena penegakan hukum. Kedua; pers sebagai fasilitator penegakan hukum. Ketiga; pers sebagai penghambat penegakan hukum.

Pertama; pers sebagai obyek penegakan hukum atau sebagai yang terkena penegakan hukum. Pers menjadi obyek penegakan hukum karena pers adalah subyek hukum (rechtsubject). Pers sebagai subyek hukum dapat mengenai pelaku pers (wartawan, redaktur, pemilik pers) atau pers sebagai lembaga. Penegakan hukum terhadap pers terjadi karena pers melakukan pelanggaran hukum (wederrechtelijk), melakukan perbuatan melawan hukum

\footnotetext{
${ }^{9}$ Bandingkan Pasal 6 UU Pers.

${ }^{10}$ Bandingkan bagian pertimbangan poin a UU No. 40 Tahun 1999 Tentag Pers.
}

(onrechtmatigedaad); yang dapat meliputi pelanggaran yang bersifat pidana, keperdataan, atau administrasi. Pelanggaran pidana dapat meliputi perbuatan seperti pencemaran nama baik, atau fitnah, atau melanggar privacy, trespassing, menyebarkan rahasia Negara,dll.

Kedua; pers sebagai fasilitator penegakan hukum. Salah satu fungsi pers, sebagai fungsi tertua, adalah menyediakan atau menyampaikan informasi kepada publik. Salah satu informasi adalah berbagai peristiwa hukum, hubungan hukum, berbagai pelanggaran hukum yang terjadi di masyarakat (berita tentang pembunuhan, kekerasan atau penganiayaan, kecelakaan lalu lintas, korupsi, pencurian, penipuan, membangun tanpa izin, sengketa hak dan lain-lain). Tidak kalah penting, fungsi pers menyampaikan informasi kepada publik tentang proses hukum yang sedang berjalan di dalam atau di luar proses peradilan.

Ketiga; pers sebagai penghambat penegakan hukum. Kita mengenal ungkapan trial by the press (peradilan oleh pers). Ungkapan ini menggambarkan, baik melalui pemberitaan atau rubrik opini publik, atau opini pers sendiri, pers telah memiliki pendapat hukum atau sekurangkurangnya mendorong publik berpendapat mengenai suatu perkara yang belum diputus pihak yang berwenang (pengadilan atau di luar pengadilan). Cara-cara pemberitaan atau penyampaian opini semacam ini tidak hanya melanggar asas praduga tidak bersalah (presumption of innocence), melainkan juga merupakan suatu bentuk menghambat proses peradilan yang adil, fair, dan imparsial (obstruction of justice), bahkan merupakan pelecehan

11 Bagir Manan, Pers,Hukum dan Hak Asasi Manusia,2016,Penerbit: Dewan Pers,Jakarta,Hal. 55-57 
terhadap tatanan peradilan (contempt of court).

Dari ketiga hubungan pers dan penegakan hukum, penulis menitikberatkan pada fungsi yang kedua yakni pers sebagai fasilitator penegakan hukum dimana merupakan fungsi pers yang tertua yakni menyediakan atau menyampaikan informasi kepada public tentang berbagai peristiwa hukum, hubungan hukum, dan berbagai pelanggaran hukum yang terjadi di masyarakat. Salah satu contohnya kejahatan korupsi.

Berdasarkan data Data Komisi Pemberantasan Korupsi (KPK) yang dipublish oleh media pers bahwa sejak 2014-2019 jenis perkara tindak pidana korupsi yang terjadi di Indonesia, didominasi oleh perkara suap yaitu sebanyak 65\% atau 602 perkara penyuapan, Selanjutnya posisi kedua yakni pengadaan barang dan jasa sebanyak $21 \%$ atau 195 perkara, ketiga disusul oleh tindak pidana penyalahgunaan anggaran sebesar 5\% atau 47 perkara, keempat kasus Tindak Pidana Pencucian Uang (TPPU) sebanyak 3\% atau 31 perkara, posisi kelima terkait persoalan pungutan atau pemerasan, yakni sebanyak 3\% atau 25 perkara, keenam terkait tindak pidana perizinan sebanyak $2 \%$ atau 23 perkara. ${ }^{12}$.

Kejahatan korupsi tersebut penting untuk diinformasikan kepada publik agar public mengetahui indeks perkembangan korupsi di Indonesia dan juga mengetahui sejauhmana aparat hukum bekerja. Dalam pengungkapan data tersebut pers memiliki peran stretegis yakni sebagai lembaga yang memberikan informasi kepada publik berkaitan dengan kejadian-kejadian korupsi, baik berupa pristiwa, data maupun tentang penanganan yang dilakukan oleh aparat penegakan hukum. Selain itu juga berkaitan dengan pembentukan opini publik tentang upayaupaya pemberantasan korupsi di Indonesia.

Kebebasan pers dalam menyampaikan informasi kepada publik, khsususnya berkaitan dengan tindak pidana korupsi tentunya harus dilandasi pada kode etik dan prinsip-prinsip jurnalistik sebagaimana diatur dalam UU Pers. Dalam undang-undang Pers diatur secara tegas dalam pasal 5 dan pasal 6 yakni pers harus menaati prinsip asas praduga tak bersalah, informasi yang tepat, akurat, dan benar, serta penghormatan terhadap Hak Asasi Manusia.

Dalam sudut pandang Hak Asasi Manusia, kebebasan pers tentunya harus dilihat dalam dua aspek, yakni Hak Asasi Manusia yang terkait dengan kebebasan pers atau media pers dalam menyampaikan informasi kepada publik dan disisi yang lain berkaitan dengan Hak Asasi Manusia warga negara untuk memperoleh informasi yang benar dan bertanggungjawab serta perlindungan Hak Warga negara dari pemberitaan media informasi yang mengabaikan perlindungan Hak Asasi warga negara seperti nama baik,kesusilaan,kriminalisi media massa sebelum proses hukum,dan sebagainya.

Hal tersebut tentunya telah diatur dalam Undang-Undang pers khususnya dalam penjelasan pasal 4 menegaskan bahwa:

"Kemerdekaan pers adalah kemerdekaan yang disertai kesadaran akan pentingnya penegakan supremasi hukum yang dilaksanakan oleh pengadilan, dan tanggung jawab profesi yang dijabarkan dalam kode Etik

\footnotetext{
${ }^{12} \mathrm{https}: / /$ mediaindonesia.com/read/detail/270337penyuapan-dominasi-kasus-korupsi-5-tahun-terakhir (diakses, 18 Maret 2020)
} 
Jurnalistik serta sesuai dengan hati nurani insan pers"

Selain dalam instrument hukum nasional, dalam instrument hukum internasional yang telah diratifikasi oleh Indonesiapun mengatur tentang pembatasan-pembatasan dalam kebebasan pers dalam upaya perlindungan Hak Asasi Manusia warga negara. Hal tersebut dapat dilihat dalam Konvenan Internasional Hak-hak Sipil dan Politik (International Convenan On Civil and Political Rights). Dalam pasal 19 point c yang menegaskan: ${ }^{13}$

"Pelaksanaan hak-hak yang diberikan dalam ayat (2) pasal ini menimbulkan kewajiban-kewajiban dan tanggung jawab khusus. Oleh karena itu dapat dikenai pembatasan-pembatasan tertentu,tetapi hal ini hanya dapat dilakukan sesuai dengan hukum dan hanya sepanjang diperlukan untuk: a) Menghormati hak-hak dan nama baik orang lain, b) Melindungi keamanan nasional atau ketertiban umum atau kesehatan atau kesusilaan umum"

Dari uraian ketentuan tersebut di atas, dapat ditemukan dua dasar pembatasan atas kebebasan pers. Pertama; atas dasar kesadaran bahwa kebebasan pers dibatasi oleh hak asasi warga negara, baik aspek kepatutan dan kesusilaan. Pembatasan ini bersifat moral (tuntutan moral) yaitu kewajiban menghormati kebebasan warga negara yang diwujudkan dalam bentuk "self cencorship". Kedua; atas dasar aturan hukum yang dibuat sesuai dengan "general will" atau yang dibuat menurut tatanan demokrasi. Berdasarkan dua bingkai pembatasan itu, meskipun kebebasan itu bersifat individual (individual freedom) tetapi tidak dapat terlepas dari kepentingan publik seperti keamanan atau kenyamanan publik (public safety). Ketika kebebasan pers dipertalikan dengan kebebasan warga negara atau kepentingan publik, kebebasan yang benar apabila disertai toleransi dan harmoni. Inilah makna "kebebasan yang bertanggung jawab".

\section{Pelembagaan Pers Penjara Sebagai Upaya Pencegahan Korupsi pada Lembaga Pemasyarakatan}

Pencegahan dan penanggulangan tindak pidana korupsi sebagai kejahatan luar biasa (Extra Ordinary Crime) di Indonesia harus dilakukan dengan upaya luar biasa juga melalui pendekatan optimalisasi system peradilan pidana (Criminal Jsutice System).

Salah satu komponen yang tidak terpisahkan dari system peradilan pidana adalah Lembaga Pemasyarakatan. Mardjono $^{14}$ mengemukankan bahwa sistem peradilan pidana (criminal justice system) adalah sistem dalam masyarakat untuk menanggulangi masalah kejahatan yang bertujuan: a) mencegah masyarakat menjadi korban kejahatan; b) menyelesaikan kasus kejahatan yang terjadi sehingga masyarakat puas bahwa keadilan telah ditegakan dan yang bersalah dipidana;c) mengusahakan agar mereka yang pernah melakukan kejahatan tidak mengulangi lagi kejahatannya. Bertitik tolak dari tujuan tersebut, Mardjono ${ }^{15}$ mengemukakan bahwa empat komponen dalam sistem peradilan Pidana (Kepolisian, Kejaksaan, Pengadilan, dan Lembaga Pemasyarakatan) diharapkan dapat bekerjasama untuk membentuk

\footnotetext{
${ }^{13}$ Adami Chazawi,2015,Tindak Pidana

Pers,Penyerangan Terhadap Kepentingan Hukum

Yang di Lindungi Dengan mempublikasikan

Tulisan,Penerbit mandar Maju,Bandung,Hal. 259
}

\footnotetext{
14 Mardjono Reksodipoetro, "Sistem Peradilan Pidana Indonesia (Peran Penegak Hukum Melawan Kejahatan), dikutip dari Hak Asasi Manusia dalam Sistem Peradilan Pidana,1994, hlm. 84-85.

${ }^{15}$ Ibid.
} 
suatu"integrated criminal justice system".

Mendukung pendapat tersebut, pakar hukum pidana yang lain yakni, Muladi $^{16}$ mengemukakan makna integrated criminal justice system adalah sinkronisasi atau keserempakan dan keselarasan, yang dibedakan dalam:1)Sinkronisasi structural (structural synchronization); yakni keserempakan atau keselarasan dalam rangka hubungan antar lembaga penegak hukum;2) Sinkronisasi substansial (substantial synchronization); keselarasan yang bersifat vertical dan horizontal dalam kaitan dengan hukum positif; 3) Sinkronisasi cultural (cultural synchronization) yakni keserempakan dan keselarasan dalam menghayati pandangan-pandangan,sikap-sikap dn falsafah yang secara menyeluruh mendasari jalannya sistem peradilan pidana.

Berbicara tentang Lembaga Pemasyarakatan yang disebut "penjara", secara historis sudah sejak zaman Belanda dapat dirujuk pada Reglement Penjara Tahun 1917. Dalam Pasal 28 ayat (1) Reglement tersebut dinyatakan bahwa, "penjara" adalah tempat pembalasan yang setimpal atau sama atas suatu perbuatan atau tindak pidana yang telah dilakukan oleh si pelaku tindak pidana dan juga sebagai tempat pembinaan terhadap narapidana atau pelaku tindak pidana. ${ }^{17}$

Terjadinya perkembangan atau pergeseran nilai dari tujuan atau inti pidana penjara tersebut sebelum menjadi Lembaga Pemasyarakatan, yang dimulai

\footnotetext{
${ }^{16}$ Muladi, Kapita Selekta Sistem Peradilan Pidana, Badan Penerbit UNDIP,1995, hlml.1-2

${ }^{17}$ Bachtiar Agus Salim, Tujuan Pidana Penjara Sejak Reglemen 1917 Hingga Lahirnya Sistem

Pemasyarakatan di Indonesia Dewasa ini (Medan,

Pustaka Bangsa, Pemikiran Hukum Guru Besar

Dari Masa ke Masa, editor Tan Kamello, 2003). hal. 129.

${ }^{18}$ Bachtiar Agus Salim, Tujuan Pidana Penjara Sejak Reglemen 1917 Hingga Lahirnya Sistem
}

dari tujuan balas dendam (retalisation) kepada pelaku tindak pidana kemudian berubah menjadi pembalasan yang setimpal (retribution) bagi si pelaku tindak pidana yang selanjutnya diikuti dengan tujuan untuk menjerakan (deterence) si pelaku tindak pidana dan kemudian diikuti juga pada awal abad ke19 sampai dengan permulaan abad ke-20, tujuan tersebut tidak lagi bersangkutan dengan memidana (punitive) melainkan bertujuan untuk memperbaiki terpidana (rehabilitation) dengan jalur resosialisasi. ${ }^{18}$

Menurut penulis Romawi ada tiga tujuan pemidanaan,yakni: $\left.{ }^{19} \quad 1\right)$ memperbaiki pribadi si penjahat, 2) membuat orang menjadi jera untuk melakukan kejahatan, c) membuat penjahat-penjahat tertentu menjadi tidak mampu untuk melakukan kejahatankejahatan yang lain,yakni penjahatpenjahat yang dengan cara lain sudah tidak dapat diperbaiki lagi. Hal tersebut sejalan juga dengan pendapat Seneca yang merujuk pada pendapat filsuf Yunani "Plato" yang menyatakan" seorang bijak tidak menghukum karena dilakukannya dosa,melainkan agar tidak lagi terjadi dosa" (nemo prudens punit, quia peccatum, sed ne peccetur $)^{20}$

Selanjutnya dalam Perkembangan konsep kepenjaraan berubah ke konsep Pemasyarakatan. Sistem Pemasyarakatan mulai dikenal di Indonesia sejak tahun 1962-1964. Saharjo, Menteri Kehakiman Indonesia pada tahun 1962 merumuskan apa yang kemudian disebut dengan filsafat pemasyarakatan. Menurut beliau, tugas kepenjaraan bukan hanya

Pemasyarakatan di Indonesia Dewasa ini (Medan, Pustaka Bangsa, Pemikiran Hukum Guru Besar Dari Masa ke Masa, editor Tan Kamello, 2003). Hal. 13

${ }^{19}$ Mopang L.Pangabean,Pokok-pokok Hukum Penitensier di Indonesia,2005,Jakarta,Penerbit UKIpress,Hal.45

${ }^{20}$ Ibid. 
melaksanakan hukuman hilang kemerdekaan, tetapi juga mengembalikan orang yang dijatuhi hukuman ke dalam masyarakat. ${ }^{21}$

Sejalan dengan konsep tersebut,maka lahirlah rezim undangundang No. 12 tahun 1995 yang menjelaskan secara gamblang konsep penjara di Indonesia, sebagaimana diuraikan dalam Pasal 2 dan Pasal 3.

"Sistem pemasyarakatan diselenggarakan dalam rangka membentuk Warga Binaan Pemasyarakatan agar menjadi manusia seutuhnya, menyadari kesalahan, memperbaiki diri, dan tidak mengulangi tindak pidana sehingga dapat diterima kembali oleh lingkungan masyarakat, dapat aktif berperan dalam pembangunan, dan dapat hidup secara wajar sebagai warga yang baik dan bertanggung jawab". (Pasal 2)

"Sistem pemasyarakatan

berfungsi menyiapkan Warga Binaan Pemasyarakatan agar dapat berintegrasi secara sehat dengan masyarakat, sehingga dapat berperan kembali sebagai anggota masyarakat yang bebas dan bertanggung jawab". (Pasal 3)

Idealitas

pemasyarakatan

tersebut, dalam realitas di Indonesia menunjukan tantangan. Dalam catatan Iqrak Sulhin ${ }^{22}$ pemasyarakatan di Indonesia memiliki beberapa problem, yakni: a) masalah otonomi (problem of autonomy), yakni masalah yang muncul karena tidak adanya otonomi dari penjara sebagai suatu organisasi. Sebagai bagian dari birokrasi negara, kondisi struktural menyebabkan perencanaan dan penganggaran sangat tergantung pada kebijakan negara. Terutama terkait dengan penganggaran untuk memenuhi kebutuhan minimum (hak-hak dasar) narapidana serta menyelenggarakan program pembinaan; b) masalah tehnologi (problem of technology), tehnologi yang diamaksudkan di sini adalah manajemen dalam penyelenggaraan pembinaan serta strategi serta instrumentasi pembinaan itu sendiri. Dukungan fasilitas yang kurang proporsional, akan berdampak pada minimnya kemampuan penjara menyelenggarakan proses pembinaan, seperti kurang variatifnya metode pembinaan yang memang harus disesuaikan dengan klasifikasi tahanan atau narapidana, kurangnya sarana prasarana dan serta kurangnya kapasitas petugas dalam memberikan pembinaan; c) masalah control (problem of control) adalah terkait dengan masalah penjara dalam mempertahankan level kepatuhan penghuninya. Penjara dianggap sebagai institusi tertutup. Oleh karena itu pengawasan eksternal baik dilakakan oleh Lembaga pemerintah lain yang berwenang maupun oleh masyarakat, cenderung sulit dilakukan. Hal ini berdampak terjadinya banyak penyimpang yang dilakukan dipenjara oleh petugas atau otoritas penjara; $d$ ) masalah prison overcrowd yakni jumlah penghuni melebihi daya tampung maksimal. Hal tersebut menimbulkan problem buruknya kondisi penjara, kurangnya kuantitas dan kualitas staf, ketidak-nyamanan staf dan pencampuran kategori narapidana.

Problematika dan tantangan pemasyarakatan secara umum sebagaimana diuraikan tersebut, secara gamblang juga ditemukan dalam praktik pemasyarakatan narapidana korupsi. Idealitas pemasyarakatan korupsi sebagai tempat pembinaan narapidana agar tercapainya tujuan yakni menciptakan efek jera terhadap pelaku tindak pidana korupsi dan juga sekaligus agar mengubah perilaku menjadi taat hukum, justru sebaliknya munculnya bebagai macam penyimpangan dan pelanggaran-

${ }^{22}$ Iqrak Sulhin,Op.Cit.Hal.131-132

${ }^{21}$ Ibid.hal.100 
pelanggaran hukum yang melibatkan narapidana korupsi dan otoritas lembaga pemasyarakatan.

Berangkat dari persoalan tersebut, maka penting dicarikan jalan dan solusi dengan pendekatan melalui pengawasan khusus yang dilakukan oleh lembaga khusus di luar dari institusi lembaga pemasyarakatan tersebut. Penulis Setuju dengan pendapat dari Iqrak Sulhin, sebagaimana dalam uraian sebelumnya bahwa salah satu persoalan yang menjadi pemicu banyaknya penyimpangan dalam lembaga pemasyarakatan adalah masalah control (problem of control) yakni terkait dengan masalah penjara dalam mempertahankan level kepatuhan penghuninya sehingga penjara dianggap sebagai institusi tertutup. Oleh karena itu pengawasan eksternal baik dilakakan oleh Lembaga pemerintah lain yang berwenang maupun oleh masyarakat, cenderung sulit dilakukan.

Salah satu gagasan penulis adalah dengan pendekatan pers khusus penjara. Lembaga pers ini dilembagakan secara permanen yang mencakup media cetak maupun elektronik, dengan tugas dan tanggung sebagaimana umumnya kegiatan jurnalistik yang meliputi mencari, memperoleh, memiliki, menyimpan, mengolah, dan menyampaikan informasi baik dalam bentuk tulisan, suara, gambar, suara dan gambar, serta data dan grafik maupun dalam bentuk lainnya yang khusus berkaitan dengan segala bentuk aktivitas, program dan kebijakan pemasyarakatan.

$\begin{array}{lrr}\begin{array}{c}\text { Oleh } \\ \text { dipikirkan }\end{array} & \begin{array}{c}\text { karena itu penting } \\ \text { kedepan }\end{array} & \text { bagaimana }\end{array}$ pengaturan khsusus tentang pers penjara sebagai lembaga pengawasan eksternal terhadap segala aktivitas lembaga pemasyarakatan. Dalam regulasi peraturan perundangan-undangan yang yang telah ada baik dalam UU Tindak Pidana Korupsi, maupun dalam UU Pers dan UU Tentang Lembaga
Pemasyaraktan tidak tersurat secara tegas tentang pelibatan pers dalam upaya pencegahan korupsi dan berbagai penyimpangan dalam lembaga pemasyarakatan. Hal tersebut dapat digambarkan sebagai berikut:

\section{UU No. 31 Tahun 1999 yang diubah dengan UU No. 20 Tahun 2001 tentang Tindak pidana Korupsi}

Dalam UU No. 31 Tahun 1999 yang diubah dengan UU No. 20 Tahun 2001 tentang Tindak pidana Korupsi tidak diatur secara khsusus tentang upaya pelibatan pers dalam upaya pencegahan korupsi. Dalam undangundang tersebut hanya diatur secara umum tentang peran partisipasi masyarakat untuk membantu upaya pencegahan dan pemberantasan tindak pidana korupsi (Ayat 1).

Peran serta masyarakat sebagaimana dimaksud dalam ayat (1) diwujudkan dalam bentuk: a. hak mencari, memperoleh, dan memberikan informasi adanya dugaan telah terjadi tindak pidana korupsi; b. hak untuk memperoleh pelayanan dalam mencari, memperoleh dan memberikan informasi adanya dugaan telah terjadi tindak pidana korupsi kepada penegak hukum yang menangani perkara tindak pidana korupsi (Ayat 2).

Jadi dalam UU Tindak Pidana Korupsi tersebut, institusi pers tidak disebut secara spesifik sebagai lembaga yang diberi ruang dalam upaya pencegahan korupsi. Hak mencari, memperoleh, dan memberikan informasi adanya dugaan telah terjadi tindak pidana korupsi sebagaiman dalam poin a ayat (1) hanya merupakan ketentuan umum bagi siapa saja bukan spesifik institusi pers itu sendiri.

\section{UU No. 40 Tahun 1999 tentang Pers}

Dalam UU Pers khususnya dalam Pasal 3 ayat (1) menegaskan Pers 
nasional mempunyai fungsi sebagai media informasi, pendidikan, hiburan, dan kontrol sosial. Penggunaan istilah kontrol sosial sebagai bentuk salah tugas pers dalam mengontrol segala kebijakan pemerintah maupun perilau kehidupan berbangsa dan bernegara secara umum.

Jadi dalam UU Pers hanya mengatur secara umum saja berkaitan dengan fungsi pers, tidak menagatur secara spesifik dalam upaya-upaya khusus seperti fungsi pers dalam upaya pencegahan korupsi.

\section{UU No. 12 Tahun 1995 Tentang Pemasyarakatan}

Dalam UU tentang

Pemasyarakatan diatur tentang Balai Pertimbangan Pemasyarakatan dan Tim Pengamat Pemasyarakatan, yakni dalam pasal 45. Tim Pengamat Pemasyarakatan terdiri dari pejabat-pejabat LAPAS, BAPAS atau pejabat terkait lainnya bertugas: a. memberi saran mengenai bentuk dan program pembinaan dan pembimbingan dalam melaksanakan sistem pemasyarakatan; b. membuat penilaian atas pelaksanaan program pembinaan dan pembimbingan; atau c. menerima keluhan dan pengaduan dari Warga Binaan Pemasyarakatan.

Dalam UU pemasyarakatan tersebut, tidak diatur secara tegas bagaimana model dan mekanisme penyampaian laporan dan informasi yang dilakukan pengamat kemasyarakaratan agar hasilnya dapat diketahui oleh publik. Disini pelibatan pers sebagai media komunikasi dan informasi massa tidak diatur secara tegas.

Berdasarkan uraian tersebut, maka penulis menggagas pentingnya pelembagaan pers penjara sebagai salah satu media control berbagai kebijakan dan program lembaga pemasyarakatan, agar tujuan pemasyarakatan sebagai lembaga pembinaan narapidana dapat terwujud sekaligus mencegah berbagai penyimpangan dalam lapas termasuk korupsi dan suap menyuap. Untuk itu ada beberapa alternative gagasan penulis: a). alternatif pertama, pelembagaan pers penjara melalui satu regulasi khusus berkaitan dengan pers khusus penjara yang mengatur tugas dan kewenangannya serta mekanisme pengawasan yang dilakukan b) alternatif kedua, pelembagaan pers penjara dengan meninjau ulang perundang-undangan yang ada, baik itu UU pers maupun UU pemasyarakatan dengan menambahkan satu ketentuan khusus berkaitan dengan pers khusus untuk penjara dengan tugas dan mekanisme pengawasannya yang khusus pula.

\section{PENUTUP}

Upaya pencegahan dan penanggulangan kejahatan korupsi dari waktu ke waktu penting dilakukan, mengingat korupsi merupakan kejahatan luar biasa yang mengancam hampir semua aspek kehidupan bangsa, baik ekonomi, social, maupun masalah demokrasi dan hukum itu sendiri. Korupsi menjadi semakin menakutkan karena korupsi sudah merasuki lembagalembaga penegak hukum yang terintegrasi dalam system peradilan pidana,seperti kerpolisian,kejaksaan, pengadilan dan lembaga pemasyarakatan yang seharusnya menjadi role model pemberantasan korupsi.

Oleh karena itu bagi penulis, pembenahan terhadap seluruh sistem peradilan pidana merupakan hal yang mendesak di lakukan. Salah satu sub system peradilan pidana yang penting dibenahi dan ditata secara baik adalah lembaga pemasyarakatan, sebab praktek penyimpangan termasuki korupsi dan suap menyuap banyak terjadi pada institusi pembinaan narapidana tersebut. Salah satu gagasan penulis adalah dengan pendekatan pengawasan secara khusus 
terhadap lembaga pemasyarakatan dengan pelembagaan khusus pers penjara. Model pengaturan ini diharapkan mampu mengontrol dan mengendalikan seluruh aktivitas dalam lembaga pemasyarakatan, sehingga pada akhirnya dapat mencegah berbagai penyimpangan termasuk korupsi dan suap menyuap dalam lembaga pemasyarakatan.

\section{DAFTAR PUSTAKA}

Adami Chazawi. 2015. Tindak Pidana Pers, Penyerangan Terhadap Kepentingan Hukum yang Dilindungi dengan Mempublikasikan Tulisan. Bandung: Mandar Maju.

Bibit Samad Rianto. 2009. Undangundang Pengadilan Tipikor dan Eksistensi Komisi Pemberantasan Korupsi, dalam Amir Syarifudin, dkk (Penyunting) Bunga Rampai Potret Penegakan Hukum di Indonesia. Jakarta: Komisi Yudisial, Republik Indonesia.

Bagir Manan. 2016. Pers, Hukum dan Hak Asasi Manusia. Jakarta: Dewan Pers. Bachtiar Agus Salim. 2003. Tujuan Pidana Penjara Sejak Reglemen 1917 Hingga Lahirnya Sistem Pemasyarakatan di Indonesia Dewasa ini (Pemikiran Hukum Guru Besar Dari Masa ke Masa, editor Tan Kamello. Medan: Pustaka Bangsa

Mardjono Reksodipoetro. 1994. "Sistem Peradilan Pidana Indonesia (Peran Penegak Hukum Melawan Kejahatan), dikutip dari Hak Asasi Manusia dalam Sistem Peradilan Pidana.
Muladi. 1995. Kapita Selekta Sistem Peradilan Pidana. Semarang: Badan Penerbit UNDIP.

Mopang L. Pangabean. 2005. Pokokpokok Hukum Penitensier di Indonesia. Jakarta: UKI-Press.

Indriyanto Seno Adji. 2006. Korupsi Kebijakan Aparatur Negara dan Hukum Pidana Jakarta: Diadit Media.

Iqrak Sulhin. 2016. Diskontinuitas Penologi Punitif,Sebuah Analisis Genealogis Terhadap Pemenjaraan. Jakarta: Prenadamedia Group.

Pemasyarakatan di Indonesia Dewasa ini (Medan, Pustaka Bangsa, Pemikiran Hukum Guru Besar Dari Masa ke Masa, editor Tan Kamello, 2003.

Saleh, Abdul Rahman. "Korupsi Tergolong Extraordinary” http://www.arsip.pontianakpost. com/berita/index.asp?Berita $=\mathrm{Pi}$ nyuh\&id=129619

https://nasional.kompas.com/read/2018/0 7/24/14081701/pimpinan-dprminta-napi-koruptor-takdiistimewakan-di-lapas.

https://wartakota.tribunnews.com/2019/1 2/02/90-persen-peredarannarkoba-berasal-dari-dalamlapas-pengendalian-cukupdengan-ponsel.

https://mediaindonesia.com/read/detail/2 70337-penyuapan-dominasikasus-korupsi-5-tahun-terakhir

UU RI No.12 Tahun 1995 Tentang Pemasyarakatan

UU RI No. 20 tahun 2001 tentang Petubahan Atas UU.No.31 tahun 1999 tentang Pemberantasan Tindak Pidana Korupsi

UU RI No. 40 Tahun 1999 tentang Pers 